\title{
Impact Of Higher Education On Earnings Of Women In The Public Sector Educational Institutions In Pakistan
}

\author{
Rummana Shah, (E-mail: rummanashah@ hotmail.com), Quaid-E-Azam University, Pakistan
}

\begin{abstract}
Formal education is one of the most important components of "human capital". The Economics of Education and especially the role of education in growth and development became prominent topics during the early years of the 1960's. T.W. Schultz, Gary Becker and others applied the new "human capital" frame work to the study of education and other activities that had until then been considered outside the mainstream of economic analysis. It is a universally accepted fact that universal primary education is very important for a country's development and so is the secondary education as it forms a basis for higher education and technical/vocational training. However, economists differ in view with respect to the importance of higher education. The main purpose of this study was to find the impact of Higher Education and Experience on the Earnings of women teaching at public sector educational institutions in Pakistan. The Higher Education Commission of Pakistan has been trying to encourage the spread of higher education in Pakistan during the past three years or so. The study tried to see whether the emphasis is well placed or not. Data was collected about the qualification level, experience and monthly "take home" salary (March 2004) of female teachers in Islamabad. Only public sector schools, colleges and a university were chosen. A sample of hundred teachers/lecturers/professors was selected from these institutions. Two equations were estimated using the Ordinary Least Square method. Log linear functions were used to estimate both the equations. The first equation uses the number of years of schooling, experience and experience squared as the three independent variables. Its result shows that an additional year of schooling increases a teacher's monthly income by $14.2 \%$ (which is higher than the previous studies) the additional year of experience increases the income by $7.4 \%$. All the coefficients are highly significant. The second equation uses six dummy variables to represent each completed level of education instead of the number of years of schooling, besides experience and its square. Its result shows that with every increase in the education level there is a substantial increase in the monthly earnings. Seven out of eight coefficients are highly significant. Thus the study concludes that Higher Education plays an important role in enhancing the earnings of women teaching at public sector educational institutions in Pakistan, besides personality building.
\end{abstract}

Key Words: Higher education; Experience; Earnings.

\section{INTRODUCTION}

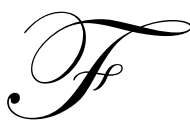

ormal education is one of the most important components of "human capital". The others being health, on-the-job training and migration. All of these are essential for the development of a country's human resources.

The Economics of Education and especially the role of education in growth and development became prominent topics during the early years of the 1960's. The empirical work on the structure of economic growth by Kuznets, Solow and Denison showed that physical capital accumulation (which until then had been treated as the central factor in most of the analytical work on growth issues) appeared to account for only a relatively limited share 
of observed real growth. The interest in the economics of education was further increased, due to the efforts of T.W. Schultz, Gary Becker and others at the University of Chicago. They applied the new "human capital" frame work to the study of education and other activities that had until then been considered outside the mainstream of economic analysis. By putting educational policy firmly within the realm of mainstream economics, the human capital approach contributed to the policy shift towards a greater emphasis on education as a way of stimulating economic development.

Pakistan has not been able to extend the capacity of the people to meet the challenges of accelerated development due to negligible amount of investment in education in the past. The slow growth of knowledge is a severe restraint to progress. The economic quality of the population remains low, when there is little knowledge of what natural resources are available, the alternative production techniques that are possible, the necessary skills, the existing market conditions and opportunities and the institutions that might be created to help the economic effort. According to the UNDP Human Development Report 2005, the Education Index for Pakistan (for 2003) was .44, it was .61 for India and .45 for Bangladesh. Where as, the HDI for Pakistan was .527 , for India it was .602 and for Bangladesh it was .520. Pakistan's gross enrolment ratios are also one of the lowest in the region, and in some districts girls participation rates are very low. The government of Pakistan has recently been trying to rectify this neglect by increased spending and better planning in this sector. Various steps are being taken to increase the enrolment rates and reduce the dropout rates at all levels of education. The Higher Education Commission has started a number of projects to promote and improve the quality of higher education in the country. The number of Colleges and Universities have increased manifold due to the encouragement given to the private sector (twenty years ago, there were about 20 Universities in the country and now there are 114 public and private Universities and degree awarding institutions). Thousands of scholarships are also being awarded to increase the number of PhDs in the country.

The study tries to see whether the emphasis on "Higher Education" is well placed or not. It tries to find the impact of "Higher Education" and "Experience" on the "Earnings" of women teaching at Public sector educational institutions in Pakistan. The paper will give a brief Review of literature about the various related studies. It will be followed by the Methodology, Estimation procedures and the Results of the present research. Finally, the last section gives the Concluding remarks.

\section{REVIEW OF LITERATURE}

The education product can be distinguished as consumption (that is, enjoyment of the fuller life permitted by education) and as direct investment (with the gains accruing "internally" in the form of increased earnings to the educated person). It is also investment from the point of view of the community as a whole. In less developed countries, the external benefits of education constitute a substantial part of the total gain. It leads to a change in the economic and social conditions. This change is an essential condition of success for a developing country. Investment in education has a long gestation period. It requires a longer planning horizon. The type of higher education should be chosen according to the future demand in the particular skill. The resource cost of education not only includes staff salaries, building and equipment but also the opportunity cost of lost income on the part of the student. Thus the rate of return on education investment is not as high as suggested by the income stream alone. It is important that the education system should be of the right type, quality and quantity.

Studies were conducted by T.W.Schultz and Gary Becker with respect to high school and college graduates in the United States. Schultz (1961) showed that even the lower limits of estimates of returns to education are equivalent to the return to non-human capital. Schultz based his estimates on the lifetime income estimates of Herman P Miller. He found a return of about 11 percent to both high school and college education. All the public and private expenditures on education and also the income foregone while attending school, were all considered by them as investment costs and none was allocated to consumption. Schultz' estimates also imply that 36 to 70 percent of the unexplained rise in the earnings of labor (in the U.S between 1929 and 1956) is explained by the returns to the additional education of workers. 
Barro (1991) tried to determine the impact of human capital and physical capital stocks on the growth rates of the countries for 1960 to 1985 in a sample of 98 countries. He found that while the initial stock of physical capital in the base year 1960 has a negative impact on growth rate, human capital measured by schooling enrolment rates in the base year had a positive impact on growth rate.

Khan and Irfan (1985) computed the private rates of return to different levels of education (Primary, Secondary and High). They found that the computed rates of return varied positively with the level of education. Shabbir (1991) tested the diploma effects in the rates of return to education in Pakistan. He showed that substantial and statistically significant diploma effects existed at four important certification levels in Pakistan, namely, Matric, Intermediate, Bachelors and Masters. After controlling for diploma years, the schooling coefficient was also found to be substantial.

Nasir and Nazli (2000) developed a human capital model for Pakistan (based on the Mincerian equation), where natural logarithm of monthly earnings was taken as the linear function of completed school years, experience and it's square. They further examined the returns to education, at different splines (levels) of education (that is, Primary, Middle, Intermediate, BA/BSc. and Professional). They conclude that each education year brings approximately 7 percent returns for wage earners. They found that higher earnings are found to be associated with higher level of education. Most of the studies for Pakistan found 7 to 8 percent increase in earnings with an additional year of schooling.

Sylwester (2002) empirically examined the effect of devoting more resources to education on the distribution of income (measured by the Gini coefficient), using a cross section of fifty countries. The study uses a twenty year period to allow sufficient time for changes. The findings suggest that public education expenditures are associated with the reduction in the level of income inequality.

Johnstone (2003) examined the rationales for cost sharing (i.e. shifting part of the higher education cost burden from governments to parents and students) as well as ideological, political and technical opposition to it. He concludes that as the governmental tax capacities are limited so there is a need for some cost sharing but for cost sharing to be compatible with access and equality, it must be accompanied by policies and programs of financial assistance. He concludes that for most forms of basic research, publicly funded higher education is still essential.

\section{METHODOLOGY}

The Human Capital model developed by Becker (1964) and Mincer (1974) is used. The natural logarithm of monthly earnings is the linear function of completed school years, experience and its square. The following two Mincerian equations are formed thus:

$\ln \mathrm{Y}_{\mathrm{i}}=\beta_{0}+\beta_{1} \mathrm{EDU}_{\mathrm{i}}+\beta_{2} \mathrm{EXP}_{\mathrm{i}}+\beta_{3}\left(\mathrm{EXP}_{\mathrm{i}}\right)^{2}+\mathrm{U}_{\mathrm{i}}$

$\ln Y_{\mathrm{i}}$ : Natural logarithm of monthly earnings.

$\mathrm{EDU}_{\mathrm{i}}$ : Completed years of schooling.

$\mathrm{EXP}_{\mathrm{i}}$ : Teaching Experience in years.

$\beta_{1}$ : Marginal rate of return to schooling.

$\beta_{2}, \beta_{3}$ : Show the relationship between earnings and experience.

$\mathrm{U}_{\mathrm{i}}$ : Error term.

The labor market considers the level of education completed and not just the number of years of schooling. It is misleading to assume a uniform rate of return to all educational levels. To examine the returns to education at different splines (levels) of education, the dummy variables are used to estimate the following equation:

$\ln Y_{i}=\beta_{1}+\beta_{2} D_{2}+\beta_{3} D_{3}+\beta_{4} D_{4}+\beta_{5} D_{5}+\beta_{6} D_{6}+\beta_{7} \operatorname{EXP}_{\mathrm{i}}+\beta_{8}\left(\mathrm{EXP}_{\mathrm{i}}\right)^{2}+\mathrm{U}_{1}$ 
Ordinary least square method is used for the regression analysis. Log linear functions are used for the estimation of the regression coefficients for both the equations. As the purpose of this paper is to see the impact of "Higher Education" so the Primary and Middle level of education is not considered and Matriculation (10 years of schooling) is considered as the first level. The six dummy variables represent the completed levels of education.

$\mathrm{D}_{1}=1$ for Matriculation (which is the excluded category), $=0$ otherwise.

$\mathrm{D}_{2}=1$ for F.A/F.Sc. (12 years of education), $=0$ otherwise.

$\mathrm{D}_{3}=1$ for B.A/B.Sc., $=0$ otherwise.

$\mathrm{D}_{4}=1$ for Masters, $=0$ otherwise.

$\mathrm{D}_{5}=1$ for M.Phil, $=0$ otherwise.

$\mathrm{D}_{6}=1$ for $\mathrm{PhD},=0$ otherwise

EXP is for experience in years as in the case of the first equation.

$\beta$ coefficients explain the variables to which they are attached.

$\ln \mathrm{Y}$ and EXP have the same meaning as in the case of the first equation.

\section{DATA / ESTIMATION PROCEDURE.}

Data was collected about the qualification level, experience and monthly "take home" salary (of February or March 2004, rounded off to nearest Rs.500) of female teachers in Islamabad. Only public sector schools, colleges and a public sector university were chosen. A sample of 100 teachers was selected at random from these institutions.

The following categories of teachers were chosen with their respective Basic Pay Scales (BPS). School teachers are hired with a minimum qualification of Matric. They are called MTT or Matric Trained Teachers (BPS: 9). Then there are TUGT or Trained Undergraduate Teachers with FA/FSc. plus training (BPS: 14). Then TGT or Trained Graduate Teacher that is, BA/BSc with B.Ed (BPS: 16). College and University lecturers are hired with a minimum qualification of MA/MSc. (BPS: 17). Assistant Professors (BPS: 18), Associate Professors (BPS: 19) and Professors (BPS: 20). All the teachers/lecturers can be promoted to a higher Pay Scale, depending upon their performance, qualification, the number of years of teaching experience and the kind of institution to which they are attached. Those with M.Phil and PhD degrees receive qualification allowance. Those teaching at Universities receive more allowances.

The sample included individuals with monthly earnings ranging between Rs.3000 (\$50) to Rs.51500 (\$860), with experience ranging from 1 year to 37 years and qualification ranging from Matric (plus training) to $\mathrm{PhD}$. The average monthly income of the sample was Rs.14290 (\$240). The average experience was 15 years and the average number of years of schooling was 14.9 years. 48 teachers were selected from schools and 52 from colleges and university. The randomly selected sample included 9 MTT, 14 TUGT, 25 TGT, 38 MA/MSc., 6 M.Phil and 8 Phd's. The selected sample belonged to BPS:9 to BPS:20. As mentioned earlier, two equations are estimated using the Ordinary Least Square method. For the first equation monthly earnings is the dependent variable. Education, experience and its square are the independent variables. For the second equation besides monthly earnings and experience, dummy variables are used from $\mathrm{D}_{1}$ to $\mathrm{D}_{6}$ for education levels of Matric, FA/FSc., B.A/B.Sc., MA/MSc., M.Phil and PhD. Log linear functions are used for estimation for both the equations

\section{RESULTS}

The estimated results of Equation 1 and Equation 2 are given below. For each coefficient, the t-statistics are given in brackets. (details are given in the Appendix Table 1 and Table 2 respectively). 


$$
\begin{aligned}
& \text { In } \hat{\mathbf{Y}}=6.412+0.142 \mathrm{EDU}+0.074 \mathrm{EXP}-0.001 \mathrm{EXP}^{2} \\
& \left(48.625^{*}\right)\left(16.645^{*}\right) \quad(8.631 *) \quad(-4.572 *) \\
& \mathrm{R}^{2}=0.891 \quad \mathrm{n}=100 \\
& \text { In } \hat{\mathbf{Y}}=8.019+0.011 \mathrm{D} 2+0.210 \mathrm{D3}+0.804 \mathrm{D} 4+0.932 \mathrm{D} 5+1.244 \mathrm{D6}+0.077 \mathrm{EXP}-0.001 \mathrm{EXP}^{2}
\end{aligned}
$$

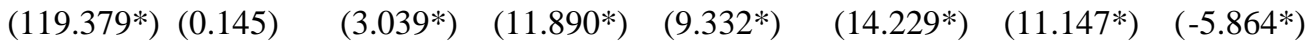

$$
\begin{aligned}
& \mathrm{R}^{2}=0.935 \quad \mathrm{n}=100
\end{aligned}
$$

Note: *indicates significance at $99 \%$ level

The highly significant coefficients of school years and experience indicate the applicability of human capital model for Pakistan. An additional year of schooling raises a teacher's monthly income by $14.2 \%$ (which is higher than the previous studies). The additional year of experience raises the income by $7.4 \%$. The concavity of age/experience -earning profile is clear from the negative and significant coefficient of experience squared. All the coefficients, including the positive constant coefficient, are highly significant. $\mathrm{R}^{2}$ is positive and quite high, which shows that the model explains the dependent variable well.

For the second equation the excluded dummy variable $\mathrm{D}_{1}$ (for Matric) is used for comparison. The coefficients for the dummy variables show that with every increase in the education level there is a substantial increase in the monthly income. Each dummy variable coefficient is positive and significantly higher than its preceding coefficient except for the coefficient for $\mathrm{D}_{2}$ (FA/F.Sc) which is positive but not statistically significant. Going from Matric to FA/F.Sc. increases earnings by only $1.1 \%$. Then a graduate earns $19.9 \%$ more than an individual with an Intermediate degree. A Master's degree substantially increases the income level by $59.4 \%$ (which is a basic qualification for getting a job at a college or a university). The M.Phil dummy variable coefficient shows an impact of $12.8 \%$ on income. A Ph.D degree leads to a $31.2 \%$ increase in income. A years' experience raises income by $7.7 \%$ (which is similar to that of the first equation). The negative coefficient of the square of experience shows concavity (that is as experience increases income also increases but at a decreasing rate). All the coefficients including the positive constant are highly significant (except for $D_{2}$ ). $R^{2}$ is positive and substantially high.

\section{CONCLUDING REMARKS}

As already discussed, the results show significant impact of higher education on monthly earnings of teachers/lecturers/professors. Thus it can be concluded that "Higher Education" plays an important role in enhancing the earnings of individuals, other than, personality building and satisfaction of personal achievement.

A teacher makes a profound impact on the minds of the future generations, so it is imperative that he/she be highly educated and satisfied with his/her economic condition. A narrow minded, lowly paid teacher can rarely bring out the best in the students where as a knowledgeable, honest and satisfied teacher will command respect and produce hard working, efficient and honest citizens. Thus the recent emphasis of the Higher Education Commission seems to be well placed. I would like to conclude in the words of Dr.Ishrat Hussain (former Governor, State Bank of Pakistan)-

"The challenges which we face in the $21^{\text {st }}$ century and the threats which the forces of globalization pose to weaker and ill prepared economies have made it even more incumbent upon us to produce the kind of manpower that is equipped to meet these challenges forcefully... Education plays the pivotal role in the thrust towards Human Development, aside from its economic value, there are other intrinsic values which good and sound education imbibe in the citizens of a nation. Tolerance of others view points, respect of human rights and dignity, appreciation of cultural diversity, fostering of civic responsibilities and nurturing the elements of national cohesion in a multiethnic society are some of the values which good and sound education can confer and promote." 
Thus, Pakistan needs to develop a good strategy of human development in which good quality education, adaptation and skill acquisition are given the primary importance. This strategy requires a different set of values, mindset and actions by individuals, educational institutions and government planners. They need to work together, to put this strategy in to practice, to be able to face, the emerging challenges of globalization and integration.

The sample only included women educationists. An alternative approach could be, to include educated individuals from all the sectors of the economy. Other interesting variables could also be included, for instance quality of education and cost of education.

\section{REFERENCES}

1. Abbas, Qaiser (2000)The Role of human Capital in Economic Growth: A Comparative Study of Pakistan and India The Pakistan Development Review 39:4 Part II 451-473.

2. Becker, Gary S.(1993), Human Capital, New York: Columbia University Press. $3^{\text {rd }}$ Edition.

3. Becker, Gary S. (1962) Investment in Human Capital: a Theoretical Analysis. Journal of Political Economy 70, Supplement.

4. Blomqvist, Ake (1986)Higher Education and the Markets for Educated Labour in LDCs: Theoretical Approaches and Implications The Pakistan Development Review 25(3): 249-270.

5. Botelho, Anabela and Ligia Costa Pinto (2004) Student's expectations of the economic returns to college education; results of a controlled experiment. Economics of Education Review (23) p 645-653.

6. Horowitz, John B. and Lee Spector (2005) Is there a difference between private and public education on college performance? Economics of Education Review 24 p.189-195.

7. Johnstone, D. Bruce (2004). The economics and politics of cost sharing in higher education: comparative perspectives. Economics of Education Review 23 p. 403-410.

8. Khan, Akhter Hassan (1997) Education in Pakistan : Fifty Years of Neglect The Pakistan Development Review 36(4) PartII :647-667

9. Khan S.R. and M.Irfan (1985). Rate of Return to Education and Determinants of Earnings in Pakistan. The Pakistan Development Review,34:3 and 4

10. Kruijk, Hans de and Frank Van Tongeren (1988) Growth, Employment and Education: An Application of Multicriteria Analysis to Pakistan. The Pakistan Development Review 27 (4) Part II 725-735

11. Machlup, Fritz (1982) Issues in the theory of Human Capital. Education as Investment, The Pakistan Development Review, 21(1):1-14

12. Meir, Gerald M. (1984) Leading Issues in Economic Development: oxford University Press

13. Mincer, Jacob(1974) Schooling, Experience and Earnings: New York : National Bureau of Economic Research

14. Nasir,Z.M. and Hina Nazli (2000) Education and Earnings in Pakistan, Pakistan Institute of Development Economics, Islamabad. (Research Report No 177)

15. Ranis, Gustav and Francis Stewart (1997) Growth and Human Development: Pakistan in Comparative Perspective The Pakistan Development Review 36(4) Part I: 333-352

16. Schultz, Theodore W. (1961) Investment in Human Capital, The American Economic Review vo1.LI,.

17. Schultz, Theodore W. (1975) The Value of the Ability to deal with Disequilibria, Journal of economic Literature. Vol:8

18. Shabbir, Tayyab (1991), Sheepskin effect in the Return to Education in a Developing country, The Pakistan Development Review 30(1):1-19

19. Sylwester, Kevin (2002), Can education expenditures reduce income inequality? Economics of Education Review 21 p. 43-52 


\section{APPENDIX}

Dependent Variable: LOG(Y)

Table 1

Method: Least Squares

Date: 04/29/04 Time: 19:44

Sample: 1100

Included observations: 100

\begin{tabular}{|c|c|c|c|c|}
\hline Variable & Coefficient & Std. Error & t-Statistic & Prob. \\
\hline $\mathrm{C}$ & 6.412 & 0.132 & 48.625 & 0.0000 \\
\hline EDU & 0.145 & 0.009 & 16.645 & 0.0000 \\
\hline EXP & 0.074 & 0.009 & 8.631 & 0.0000 \\
\hline $\mathrm{EXP}^{\wedge} 2$ & -0.001 & 0.000 & -4.572 & 0.0000 \\
\hline R-squared & 0.891 & \multicolumn{2}{|c|}{ Mean dependent variable } & 9.339 \\
\hline Adjusted R-squared & 0.888 & \multicolumn{2}{|c|}{ S.D. dependent variable } & 0.671 \\
\hline S.E. of regression & 0.225 & \multicolumn{2}{|c|}{ Akaike info criterion } & -0.109 \\
\hline Sum squared residual & 4.846 & \multicolumn{2}{|c|}{ Schwarz criterion } & -0.005 \\
\hline Log likelihood & 9.458 & \multicolumn{2}{|c|}{ F-statistic } & 261.949 \\
\hline Durbin-Watson stat & 1.649 & \multicolumn{2}{|c|}{ Probability(F-statistic) } & 0.0000 \\
\hline
\end{tabular}

Dependent Variable: LOG(Y)

Table 2

Method: Least Squares

Date: 04/29/04 Time: 15:39

Sample: 1100

Included observations: 99

Excluded observations: 1

\begin{tabular}{|c|c|c|c|c|}
\hline Variable & Coefficient & Std. Error & $\mathrm{t}$-Statistic & Prob. \\
\hline $\mathrm{C}$ & 8.0198 & 0.067 & 119.379 & 0.0000 \\
\hline D2 & 0.0112 & 0.077 & 0.145 & 0.8849 \\
\hline D3 & 0.210 & 0.071 & 2.941 & 0.0042 \\
\hline D4 & 0.802 & 0.067 & 11.890 & 0.0000 \\
\hline D5 & 0.926 & 0.099 & 9.332 & 0.0000 \\
\hline D6 & 1.282 & 0.090 & 14.229 & 0.0000 \\
\hline EXP & 0.077 & 0.007 & 11.147 & 0.0000 \\
\hline $\mathrm{EXP}^{\wedge} 2$ & -0.001 & 0.0001 & -5.864 & 0.0000 \\
\hline R-squared & 0.935 & \multicolumn{2}{|c|}{ Mean dependent variable } & 9.351 \\
\hline Adjusted R-squared & 0.931 & \multicolumn{2}{|c|}{ S.D. dependent variable } & 0.663 \\
\hline S.E. of regression & 0.175 & \multicolumn{2}{|c|}{ Akaike info criterion } & -0.575 \\
\hline Sum squared residual & 2.774 & \multicolumn{2}{|c|}{ Schwarz criterion } & -0.365 \\
\hline Log likelihood & 36.466 & \multicolumn{2}{|c|}{ F-statistic } & 188.981 \\
\hline Durbin-Watson stat & 1.501 & \multicolumn{2}{|c|}{ Probability(F-statistic) } & 0.0000 \\
\hline
\end{tabular}


Graph 1

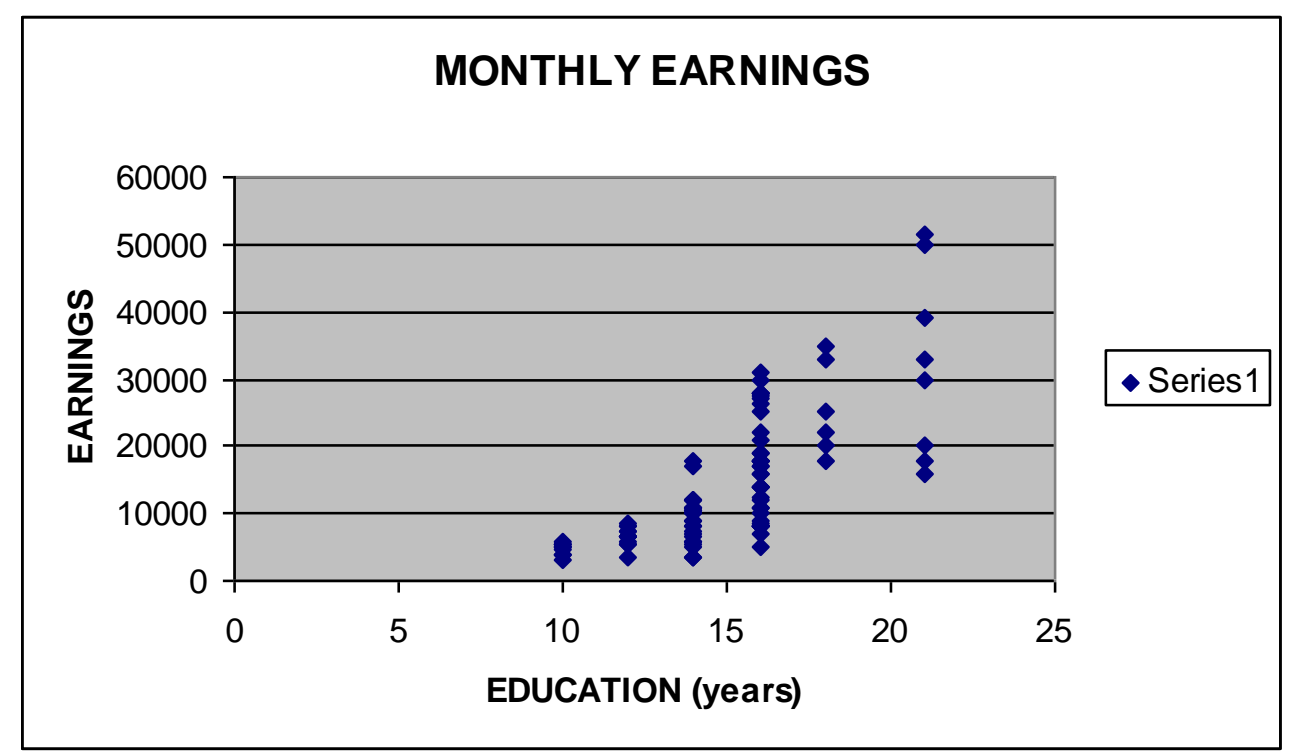

Graph 2

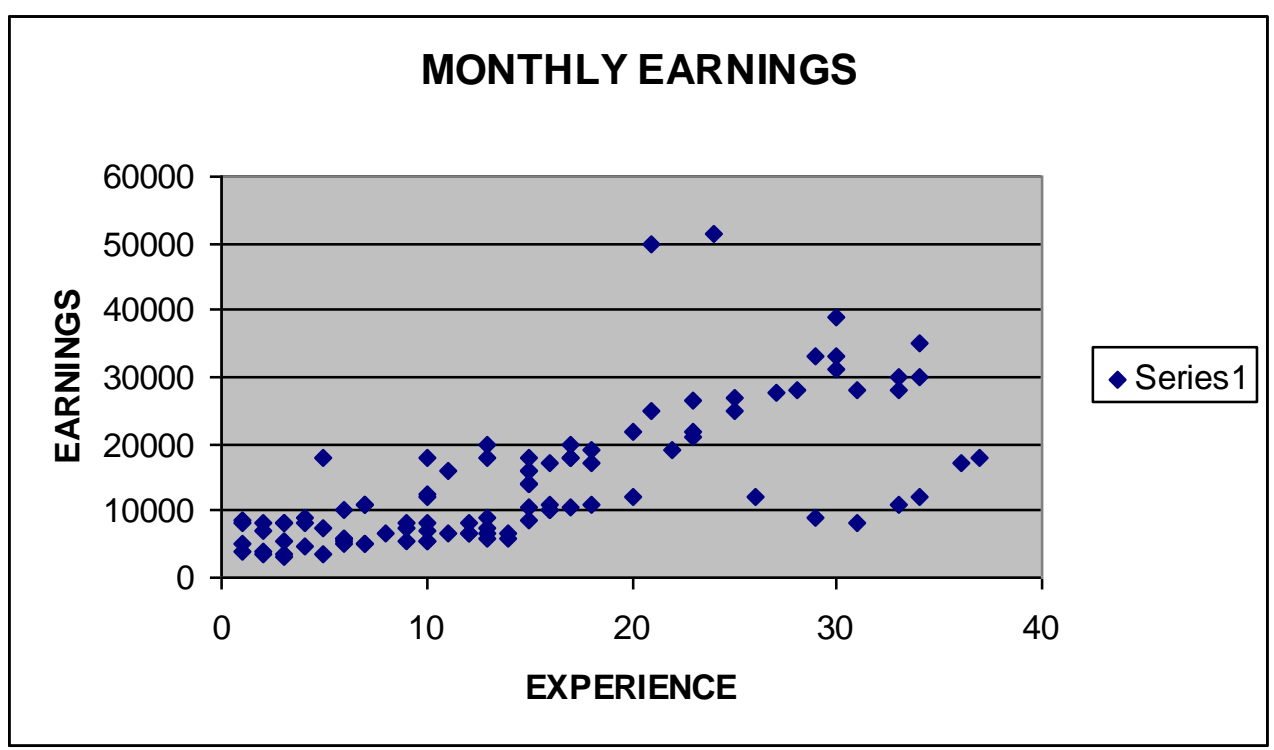

